УДК 347.4

DOI https:/ / doi.org/10.32837 / yuv.v0i4.1968

\author{
П. Гуйван, \\ кандидат юридичних наук, заслужений юрист України, \\ професор \\ Полтавського інституту бізнесу
}

\title{
ПРО ЧАСОВІ МЕЖІ ЗДІЙСНЕННЯ СУБ'ЄКТИВНОГО ПРАВА В РЕГУЛЯТИВНИХ ЦИВІЛЬНИХ ПРАВОВІДНОСИНАХ
}

\begin{abstract}
Правовідношення - це урегульоване правом та охоронюване державою суспільне відношення, учасники якого виступають як носії взаємно кореспондуючих один одному юридичних прав та обов'язків [1, с. 479]. Воно розвивається як у просторі (шляхом реалізації своїх сутнісних елементів), так і обов'язково в часі. Майже в кожній четвертій статті Цивільного кодексу України в тому чи іншому вигляді прослідковується вплив фактору часу, певним чином зазначається про наслідки, пов'язані зі спливом чи настанням строків. Час тісно пов'язаний із внутрішніми характеристиками суб'єктивного права особи та визначає період існування цього права. У правовій нормі часовий елемент зазвичай проявляється як пряма вказівка на строк чи термін, проте може мати й інший вигляд, наприклад, коли вказується про своєчасність та розумність виконання тощо. Без перебільшення можна сказати, що саме за допомогою встановлення матеріально-правових строків досягається визначеність суб'єктивних прав учасників цивільних відносин. Питання про строки в цивільних правовідносинах завжди були об’єктом прискіпливої уваги науки.
\end{abstract}

Однією з головних засад сучасного майнового обороту $€$ принцип належного виконання зобов'язань, сутність якого полягає в тому, що виконання має бути проведене учасниками взаємин належним чином відповідно до умов договору та вимог законодавства, а за відсутності таких умов та вимог - відповідно до звичаїв ділового обороту або інших вимог, що звичайно ставляться (ст. 526 ЦК України, ч. 1 ст. 193 ГК України). Саме в результаті належного виконання найбільшою мірою задовольняються інтереси кредитора. Атрибутом виконання зобов'язання за договором є сторони, строк та місце виконання. Питання про строки (терміни) виконання зобов'язання контрагентом за договором у регулятивному режимі $€$ дуже суттєвим, адже від визначення моменту, з якого наступає обов'язок боржника виконати певне зобов'язання, та моменту, яким закінчується такий обов'язок, тобто від встановлення строку виконання зобов'язання, залежить можливість подальшого здійснення вірителем (кредитором) свого суб'єктивного права i, зрештою, його захисту. Нині у цивілістиці досить безспірною $€$ позиція щодо обмеженості будьякого суб'єктивного права, якщо межі права не встановлені, здійснити його неможливо. Але, на жаль, позиція стосовно строків існування суб'єктивного права як одного із факторів, що впливає на межі поведінки управненої особи, а також про обмеження права певними строками, не набула усталеного характеру.

У наукових працях питання часового впливу на можливість реалізації суб'єктивного права в межах регу- 


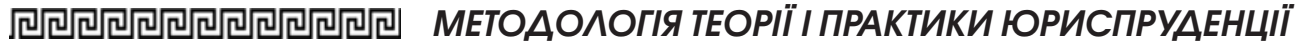

лятивного правовідношення вивчалися такими вченими, як M.M. Агарков, В.П. Грибанов, О.С. Йоффе, В.В. Луць, С.М. Братусь, 3.В. Ромовська, П.М. Рабінович, С.О. Сліпченко тощо. У цих роботах здійснено аналіз темпорального складника права особи на вчинення власних продуктивних дій та вимагання необхідної поведінки від контрагента. Однак основні проблеми організації взаємодії суб'єктів в часі на рівні уповноважена особа зобов'язана особа залишаються не вирішеними. Зокрема, практично не визначене місце строків у цілісній системі факторів, які зумовлюють належне здійснення права і відмежовують його від зловживання, виходячи 3 його призначення та природи юридичного впливу на опосередковувані відносини. На жаль, строк у цивільному праві переважно не в контексті його впливу на зміст суб'єктивного права, а як окреме соціально-правове явище. А це, так чи інакше, призводить до ізольованого аналізу та можливої звуженої оцінки його юридичної сутності. На досягнення визначеності в даному питанні й спрямована дана праця.

Правовідношення - це сукупність прав та обов'язків контрагентів. Суб'єктивне право може виникати як результат волевиявлення особи. До прикладу, укладаючи договір оренди майна, сторони створюють своїми діями право користування та володіння певним майном. Проте воно може виникати і поза волею управненої особи, наприклад, право громадянина на спадщину, право на відшкодування нанесеної шкоди тощо [2, с. 117]. Навпаки, реалізація суб'єктивного права завжди відбувається в результаті конкретних вольових вчинків особи, спрямованих на перетворення в дійсність закладених у праві можливостей поведінки. Причому в одному правилі неможливо в повній мірі відобразити порядок поведінки з урахуванням конкретних особливостей окремих випадків. I хоча будь-яке правило намагається досягти якомога більшого ступеню узагальнення, в ньому завжди залишається той чи інший елемент абстрактності. C.M. Братусь відзначав, що законодавча конкретизація суб'єктивного права все одно не охопить усіх можливих його проявів, оскільки норма закону залишається загальним правилом поведінки [3, с. 80-81]. При цьому йдеться не про конкретні вираження назовні можливої поведінки, що становить зміст суб'єктивного права, а про варіанти вчинків, спрямованих на реалізацію суб'єктивного права. Отже, незважаючи на те, що в цивільно-правових нормах визначається загальний порядок поведінки управненої особи, часто відбувається ii особливе регулювання в межах однотипових відносин. У цих діях знаходить відображення не тільки воля управненої особи, а й специфічні особливості конкретного випадку.

Здійснення суб'єктивних цивільних прав має обмеження в часі. Так, досить часто період реалізації права встановлюється відповідними нормами законодавства, тобто фактично в нормативному порядку визначаються межі здійснення особою свого права. Як правило, строк існування суб'єктивного права збігається зі строком реалізації права, і тому поняття «існування» та «здійснення» суб’єктивного права мають тотожній зміст. Зокрема, це характерно для гарантійних строків, протягом яких особа вправі використовувати якісний товар та виявляти його недоліки. Відповідно, пропуск вказаного гарантійного строку припиняє не тільки можливість вчиняти дії щодо подальшого пред'явлення вимог з усунення недоліків, а й саме існування подібної правомочності особи. Форма реалізації принципу справедливості, добросовісності й розумності являє собою порядок втілення його вимог у поведінку суб'єктів цивільного обороту, у взаємовідносини між ними. У матеріальних відносинах здійснення 
принципу справедливості та розумності зазвичай пов'язується із встановленням меж суб'єктивних матеріальних прав контрагентів [4, с. 11]. Зміст практичного застосування правила про реалізацію суб'єктивного матеріального права протягом строку його існування можна звести до науково обгрунтованого принципу здійснення цивільних прав. За своєю правовою силою зазначений принцип полягає в законодавчому закріпленні загального обов'язку для будь-якої управненої особи здійснювати належні їй повноваження лише в межах змісту відповідного суб'єктивного матеріального права [5, с. 12]. Іншими словами, реалізація суб'єктивного права можлива лише в певних межах, що характеризують його зміст, строк та характер здійснення. Не викликає сумнівів той факт, що межі здійснення права визначаються не тільки його змістом, встановленим згідно з правовими приписами, котрі містяться в конкретних нормах законодавства, а й часовими рамками існування [6, с. 28-29]. Будь-які дії, вчинені особою поза межами тривалості ї права, слід розглядати як правопорушення.

Отже, надзвичайно актуальним $є$ встановлення в кожному конкретному випадку тривалості строку, протягом якого можлива реалізація суб'єктивного права. У переважній кількості випадків така задача не є складною: час існування права встановлений нормативно або за згодою учасників правовідношення. Разом із тим, на відміну від положень кримінального чи адміністративного законодавства, які досить чітко окреслюють сферу дозволеної (забороненої) поведінки, в тому числі й щодо ї тривалості, цивільно-правові норми, побудовані на принципі дозвільності, часто (i це продиктовано специфікою предмета регулювання) містять дозволи загального характеру. У Цивільному кодексі України досить широко запроваджені такі строки, як необхідні, розумні, як тільки стане можливо тощо [7, с. 467]. Це у свою чергу передбачає необхідність судового тлумачення вказаних термінів у разі виникнення спору. Проте, як правильно вказував М.С. Малеїн, судовий розсуд не $€$ конкуренцією закону, він сам - прояв волі законодавця, який нормативно передбачив доцільність такого розсуду з точки зору суспільства [8, с. 56].

Та як би там не було, проблема належного здійснення матеріального права виключно в тих межах (в тому числі й часових), що встановлені нормативно чи за згодою учасників правовідношення, продовжує залишатися актуальною. Окремі сучасні дослідники обстоюють позицію, згідно 3 якою правовідносини $є$ саме формою реалізації права, будучи наслідком спеціально-юридичної форми правового впливу - правового регулювання, інструментом переходу загальних моделей у площину конкретних заходів поведінки - суб'єктивних прав і юридичних обов'язків для цих суб'єктів [9, с. 60-61]. Гостроти цій проблемі, зокрема щодо темпоральної визначеності, додають іноді не виважені та відверто невдалі правові акти, що видаються органами влади. Достатньо навести подібного роду документи, прийняті на рівні законів України. Так, закон встановлює якусь аморфну, квазіправову можливість здійснення права орендаря користуватися протягом часу до одного місяця чужим майном після вичерпання змісту цього права - закінчення договору оренди. Такий підхід виглядає досить дивним та неправовим, насамперед з огляду на те, що коли орендодавець навіть у тридцятий день після закінчення дії договору заявить про його розірвання, правочин буде припинений від моменту спливу його строку. Тобто заднім числом. А місячне користування виявиться неправомірним. Отже, відверто проглядає абстрактність побудованого силогізму та його практична складність, а часом і недієвість. 


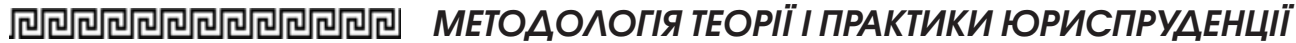

I вже зовсім критично має бути оцінено редакцію ч. 3 ст. 267 ЦКУ, згідно з якою закінчення позовної давності (за доктринальним визначенням - строку існування права на позов) не погашає суб'єктивного охоронного повноваження (позовного домагання), допоки цього не попросить відповідач. Останній же $€$ фігурантом не матеріального правовідношення, а зовсім іншого за сутністю - процесуального, котре регулюється нормами публічного права, i, зрештою, може взагалі ніколи не виникнути. Тож, за ідеєю нашого законодавця, матеріальне право на позов, навіть попри сплив строку на його реалізацію, існує скільки завгодно довго, а іноді - вічно. На жаль, подібні антиправові підходи законодавця не $€$ виключенням, і до якого б із численних прикладів ми не зверталися, в кожному випадку впадає в очі невідповідність між абстрактною конструкцією нормативно встановленого правила та конкретними життєвими ситуаціями.

Подібні підходи практично зводять нанівець усі ті теоретичні побудови, що були здійснені науковцями 3 приводу неправомірності реалізації суб'єктивного матеріального права поза його межами. Між тим ці доктринальні напрацювання заслуговують на увагу. Усі дослідники питання сходяться на тому, що здійснення права поза його межами не відповідає засадам цивілістики. Але далі починаються розбіжності: одні вчені охоплюють таке порушення поняттям «зловживання правом» [10, с. 16], інші - $з$ цим не погоджуються. Ми підтримуємо позицію останніх: використання права поза межами його дії не може кваліфікуватися як зловживання правом, бо насправді жодного права вже не існує. Для зловживання правом треба ним володіти. Оскільки вказаний прояв за відсутності права $€$ поведінкою всупереч праву, то він підпадає під визначення звичайного правопорушення [8, с. 63].
Розглянемо дане питання 3 темпоральної точки зору. Вчинки, здійснені суб'єктом права поза періодом ix існування, навіть якщо вони відповідають обсягу повноважень особи, слід розглядати не інакше, як здійснення дій, що не становлять повного змісту права, тобто як вчинення їх без належних підстав. У результаті може настати відмова в захисті права у зв'язку з неналежністю його особі. На жаль, у нашому законодавстві дане питання не врегульоване (ба, більш того, як вказувалося вище, існують норми протилежного штибу, котрі дозволяють реалізацію права поза межами його змісту). Що ж у такому разі слід розуміти як зловживання правом? На це питання дається відповідь у численних наукових дослідженнях, і така відповідь $є$ цілком коректною. Вихідним постулатом тут зазвичай приймається доктринальне визначення, що реалізація цивільних прав має відбуватися відповідно до їхньго призначення. Тобто згідно з тією метою, заради досягнення якої покликане право, воно має бути спрямовано на певний конкретний результат. Зазначена мета, спрямовуючи поведінку правоволодільця, проявляється у змістові права $[11$, с. 79-84]. Отже, наукова думка 3 часом поєднала ці два поняття: «зловживання правом» та «здійснення права всупереч його призначенню». Під час розгляду спорів відмова у захисті права судом має настати у випадку, коли матеріали справи свідчать про вчинення громадянином чи юридичною особою дій, які можуть бути кваліфіковані як зловживання правом, зокрема дій, що мають за мету нанесення шкоди іншим особам. Закон (ст. ч. 6 ст. 13, ч. 7 ст. 319 ЦКУ) також вказує на можливість відмови у захисті цивільного права в разі його здійснення всупереч призначенню.

Утім, подібне розуміння сформувалося в цивілістиці не відразу. У літературі мала місце і певною мірою досі триває полеміка 
стосовно самої можливості зловживання правом та відмови в захисті, якщо носій права діє в рамках свого права. Зокрема, М.M. Агарков відкидав подібний вплив на правоволодільця, а критерії неналежності використання права вважав ненадійними. Він стверджував, що оскільки право надане особі, то діi ii в межах права відповідають його меті й призначенню [12, с. 435]. Окремі сучасні дослідники, вже керуючись новими підходами щодо обмеження матеріальних прав, також заперечують можливість зловживання суб'єктивним правом так же, як і перевищення меж його здійснення [13, с. 84]. Адже, як зазначають дані науковці, саме зведення свободи особи до рамок матеріального зобов'язання $€$ вже обмеженням. С.M. Братусь, навпаки, вказував на реальну можливість зловживання правом і наполягав на запровадженні адекватного юридичного реагування. Адже ступінь конкретизації суб'єктивного права, виражений у певній правовій нормі, не настільки значний, щоб чітко визначити виключний перелік припустимих дій та унеможливити прояв ініціативи в здійсненні інших вчинків. Отже, відповідна норма права залишається загальним правилом поведінки, що призводить до необхідності встановлення критеріїв оцінки правомірності тих чи інших вчинків носія права щодо їхньої відповідності його призначенню. При цьому автор зазначав, що в основу вказаних критеріїв має покладатися відповідність певних дій щодо реалізації свого права моральним засадам суспільства [3, с. 80-81, 84]. Зрозуміло, що в такому разі суттєво зростає значення суб'єктивного фактору, підвищується роль судового розсуду, що не є бажаним.

Сучасна доктрина та законодавство притримують тези про можливість зловживання правом його носієм. При цьому очевидно, що таке зловживання є вчиненням упов- новаженим дій «у своєму праві», проте ці дії спрямовані проти інших охоронюваних прав та інтересів [14, с. 192].У цивілістицізараззагальноприйнятною вважається думка, відповідно до якої здійсненням суб'єктивного права $є$ вчинення управненою особою окремих дій у межах існуючих у неї як суб'єкта права повноважень. Якщо ж способи реалізації права виходять за встановлені законом суспільно бажані напрями здійснення права, це кваліфікуються як зловживання правом. Сказане значною мірою справедливо в разі реалізації права всупереч його призначенню чи на шкоду інтересам інших осіб. Зокрема, законодавство багатьох країн прямо забороняє так звану шикану: використання права виключно з метою нанесення шкоди іншій особі (див., наприклад, пар. 226 Німецького цивільного укладення). Разом із тим не можна погодитися $з$ тим, що зловживання правом є поведінкою носія права всупереч його змісту. Адже у разі, коли вчинок особи не відповідає змістові належного їй права, їі дії мають кваліфікуватися як протиправні. Саме такими (неправомірними) є вчинки особи щодо здійснення права поза часовими межами його існування. Їх не можна визнавати зловживанням правом, оскільки на час здійснення зазначене право особі вже/ще не належало [15, с. 80-81]. Натомість слід погодитися з тезою, що зловживання правом пов'язане не зі змістом самого права, а з його здійсненням [16, с. 54-55], тому вчинення окремих дій, як правомірних, так i неправомірних, поза межами змісту права слід кваліфікувати як такі, що не спираються на суб'єктивне право.

Із проведеного дослідження можна дійти певних висновків. Не можна прийняти позицію, згідно 3 якою зловживання правом $є$ здійсненням певних учинків уповноваженим, котрі виходять за межі суб'єктивного права.

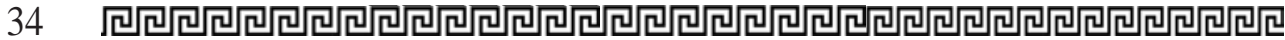




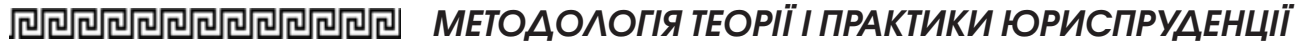

Такий підхід, хочемо ми того, чи ні, неодмінно приведе до позиціі, що реалізація суб'єктивного права поза його межами або змістом також є зловживанням правом. Проте хибність такої позиції яскраво висвітлюється під час аналізу можливостей реалізації матеріального права поза часовими межами його існування. Стосовно здійснення управненою особою повноважень, що становлять зміст суб'єктивного права, до початку існування чи після закінчення права, справедливим буде твердження M.M. Агаркова, що такі дії відбулися за межами права і тому не можуть вважатися зловживанням правом [12, с. 427]. Зрозуміло, що пред’явлення уповноваженою особою вимог поза межами здійснення права (скажімо, після закінчення договору) потягне неможливість його реалізаціі. Особа здійснила юридично значимий вчинок за межами строків існування певного суб'єктивного права, тому буде помилковим вважати іï суб'єктом, що реалізує (вживає) своє право. Подібні дії слід розглядати не як зловживання правом, а як протиправні.

Стаття присвячена дослідженню актуального наукового питання про часові межі здійснення суб'єктивного права в регулятивних правовідносинах. Надається правове визначення правовідношення як урегульованої законом суспільної взаємодї, учасники якої мають взаємно кореспондуючі юридичні права та обов'язки. Регулятивні правовідносини мають ту особливість, що їхня реалізащія відбувається як бажана поведінка суб'єктів иляхом виконання вчинків, прямо передбачених змістом відповідного зобов'язання. Здійснення суб'єктивних иивільних прав має обмеження в часі. Підстави таких обмежень, іхній характер та вплив на дієвість самого права вивчаються в роботі. Наводиться особиста позиція автора щодо доктринального визначення понять «існуван- ня» та «здійснення» суб'єктивного права, доводиться, що зазвичай вони мають однаковий зміст. Саме протягом існування права можна його здійснити, поза даними межами - це неможливо. Тому надзвичайно актуальним є встановлення в кожному конкретному випадку тривалості строку, протягом якого можлива реалізація суб’єктивного права. Особливо є важливим, коли законодавеиь встановлюе тривалість відношення у вигляді необхідних, розумних та інших подібних періодів. Вважаємо, що вони є визначеними, а їхня тривалість набувае визначеності шляхом застосування звичаїв ділового обороту. Утім, бажано звести дане правозастосування до мінімуму, уникаючи зайвого суб'єктивізму.

У роботі проаналізовано теоретичні побудови, щзо були здійснені науковиями з приводу неправомірності реалізації суб'єктивного матеріального права поза його межами. Ретельно досліджена наукова полеміка з даного приводу, за якою одні вчені охоплюють таке явище поняттям «зловживання правом», а інші - $з$ иим не погоджуються. Автор аргументовано обтрунтовуе останню позииію. Використання права поза межами його дії не може кваліфікуватися як зловживання правом, бо насправді жодного права вже не існує. Для зловживання правом треба ним володіти. Оскільки вказаний прояв за відсутності права $\epsilon$ поведінкою всупереч праву, то він підпадає під визначення звичайного правопорушення. Саме такими (неправомірними) є вчинки особи щодо здійснення права поза часовими межами його існування. Їх не можна визнавати зловживанням правом, оскільки на час здійснення зазначене право особі не наленало.

Ключові слова: зловживання правом, суб'єктивне право, регулятивне правовідношення. 
Guyvan P. About time limits of realization of the subjective right in regulatory civil legal relations

The article is devoted to the study of a topical scientific issue about the time limits of the exercise of subjective law in regulatory relations. It provides a legal definition of a legal relationship as a social interaction regulated by law, the participants of which have mutually corresponding legal rights and obligations. Regulatory legal relations have the feature that their implementation takes place as a desirable behavior of the subjects by performing actions directly provided for in the content of the relevant obligation. The exercise of subjective civil rights is limited in time. The grounds for such restrictions, their nature and impact on the effectiveness of the law itself are studied in the paper. The author's personal position on the doctrinal definition of the concepts of "existence" and "exercise" of subjective law is given, it is proved that they usually have the same meaning. It is during the existence of the law that it can be exercised, outside these limits it is impossible. Therefore, it is extremely important to establish in each case the duration of the period during which the exercise of subjective rights is possible. This is especially important when the legislator sets the duration of the relationship in the form of necessary, reasonable and other similar periods. We believe that they are definite, and their duration is determined by the application of business practices. However, it is desirable to minimize this enforcement, avoiding excessive subjectivity.

The paper analyzes the theoretical constructions made by scientists about the illegality of the implementation of subjective substantive law outside it. The scientific controversy on this subject has been carefully studied, according to which some scholars cover such a phenomenon with the concept of "abuse of rights", while others do not agree with it. The author substantiates the last position. The use of a right outside its scope cannot be qualified as an abuse of a right, because in fact no right exists anymore. To abuse a right, you must own it. Since this manifestation in the absence of law is a behavior contrary to law, it falls under the definition of a common offense. Such (illegal) are the actions of a person to exercise the right outside the time limits of its existence. They cannot be considered an abuse of rights, because at the time of exercise this right did not belong to the person.

Key words: abuse of law, subjective law, regulatory relationship.

\section{Література}

1. Теория государства и права : учебник / подред.Н.И. Матузова, А.В. Малька. Москва : Юрист, 1997. 642 с.

2. Харитонова O.I. Співвідношення категорій «правовідносини інтелектуальної власності» та «регулятивні, організаційні та охоронні правовідносини». Актуальні проблеми держави і права. 2012. Bun. 65. C. $115-125$.

3. Братусь С.H. O пределах осуществления гражданских прав. Правоведение. 1967. № 3. C. 79-86.

4. Бабич І.Г. Принщии справедливості в римському праві та зобов'язальному праві України : автореф. дис. ... канд. юрид. наук. Одеса, 2006. 22 c.

5. Луць В.В. Строки $і$ терміни у цивільному праві : монографія. Київ : Юрінком Iнтер, 2013. $320 \mathrm{c}$.

6. Гуйван П.Д. Правовая природа гражданско-правовых сроков. LEGEA SI VIATA. 2015. № 6/2 (282). C. 26-30.

7. Ромовська З.В. Українське цивільне право. Загальна частина. Академічний курс : підручник. Київ: Атіка, 2005. 560 с.

8. Малеин Н.С. Гражданский закон и права личности в СССР. Москва : Юридuч. лuт-pa, 1981. 216 c.

9. Ромащенко I. Поняття циивільного правовідношення та його структура. Юридичний журнал. 2014. № 2/3. С. 59-63.

10. Белоножкин А.Ю. Содержание и форма злоупотребления субъективным 


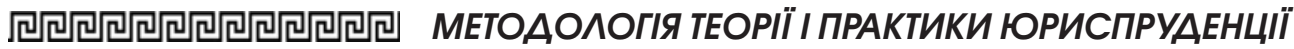

гражданским правом : автореф. дисс. ... канд. юрид. наук. Волгоград, 2005. 22 с.

11. Грибанов В.П. Предель осуществления и защиты гражданских прав. Москва: Рос. Право, 1992. 208 с.

12. Агарков М.М. Проблемы злоупотребления правом в советском гражданском праве. Изв. Аккад. наук СССР. Отд. экономики и права. 1946. № 6. С. 422-436.

13. Мічурін Є.О. До природи обмежень майнових прав фізичних осіб. Форум права. 2006. № 3. С. 81-86.
14. Филиппов П.М., Белоножкин А.Ю. Новое определение субъективного гражданского права и злоупотребление им. Волгоград : ВА МВД России, 2009. 248 с.

15. Гуйван П.Д. Теоретичні питання строків у приватному праві : монографія. Харків : Право, 2014. 632 с.

16. Емельянов В. Запрет злоупотребления гражданскими правами. Законность. 1999. № 10. С. 52-55. 